\title{
A New Technique for Research on Wound Healing through Extraction of Mandibular Lower Incisors in Wistar Rats
}

\author{
Christian Khoswanto ${ }^{1}$ \\ ${ }^{1}$ Department of Oral Biology, Faculty of Dentistry, Airlangga \\ University, Surabaya, Indonesia
}

\begin{abstract}
Address for correspondence Christian Khoswanto, DMD, MSc, PhD, Department of Oral Biology, Faculty of Dentistry, Airlangga University, Jl. Mayjend. Prof. Dr. Moestopo No. 47, Surabaya 60132, Indonesia (e-mail: christiankhoswanto@hotmail.com).
\end{abstract}

\begin{abstract}
Keywords

- tooth extraction

- mandibular incisors

- alveolar bone healing

Objective The aim of this study was to explain a new technique for research on wound healing through extraction of mandibular lower incisors in Wistar rats.

Materials and Methods Fifty Wistar rats were used from studies using the experimental animal to investigate the effects of wound healing drugs on alveolar bone. The mandibular incisors of the Wistar rats were extracted using a special modified bein and special pulling pliers under general anesthesia. The tooth socket after extraction was closed using a 5.0 suture nylon needle.

Results The results of this technique used in this extraction showed $2 \%$ incisor tooth fracture and 3\% bleeding, and that all fractured teeth could be removed properly, and bleeding could be stopped after suturing.

Conclusion The new techniques we use can be useful for research on mucosal and alveolar bone healing, specifically finding new types of drugs to accelerate wound healing after alveolar bone post extraction.
\end{abstract}

\section{Introduction}

Currently, many studies are using animals to examine wound healing. Some of them use rats, dogs, rabbits, and even monkeys. Animals that are often used to find new types of medicines for wound healing in research studies are rats. ${ }^{1,2}$ Wound healing in tooth extraction is needed in animal models so that the effect of drugs given can contribute to faster recovery. The process of wound healing in hard tissue that involves the alveolar bone is very complex because it involves soft and hard tissues. What is required is a drug that can accelerate the healing of tooth extraction wounds. Several models of tooth extraction using molar teeth in both the maxilla and mandible have been performed, but models that use incisors are still rarely used because it is feared that they will be difficult to use, considering the Wistar incisors are quite long and thin. So, they will break easily when the tooth is extracted. The use of incisors as animal models is attempted in wound healing research, giving some advantages to the long root tooth socket, allowing the drug to last long in the socket, and making it effective to know the role of the drug. Wistar rats were also able to chew food using the remaining three incisors and molar teeth. Wistar rats have four incisors, so removing one incisor does not cause death in these animals. ${ }^{3-7}$

\section{Materials and Methods}

We used a new technique to extract the incisors of Wistar rats used in research to find wound-healing remedies for tooth extraction. Fifty Wistar rats were used in this study. All research procedures were approved by the Airlangga University Ethics Committee. Animals were obtained from the Faculty of Veterinary Medicine, Airlangga University (animals breeding), were chosen to homogenize with male sex, age 3 months, body weight 150 to $200 \mathrm{~g}$, healthy with agile movements, feathers not easily fall off, no injuries to all parts of the body and decay teeth. Experimental animals that met the criteria were then separated and put into a cage for 
adaptation for 1 week. Experimental animals in the adaptation process were fed and provided water ad libitum, with husk replacement every 2 days. Before the treatment started, rats were randomized into cages of size $40 \times 30 \times 20 \mathrm{~cm}$, containing 2 mice per cage with a baffle., ${ }^{7.8}$

Wistar rats were given anesthesia using ketamine combined with xylazine intraperitoneally as much as $0.1 \mathrm{~mL} / 10 \mathrm{~g}$ body weight (BW). Dose was prepared by mixing $1.0 \mathrm{~mL}$ of $100 \mathrm{mg} / \mathrm{mL}$ ketamine with $0.5 \mathrm{~mL}$ of $20 \mathrm{mg} / \mathrm{mL}$ xylazine. The volume of the existing ketamine and xylazine mixture was added to saline solution to reach $10 \mathrm{~mL}$ in total. From this $10 \mathrm{~mL}$, the total combination of ketamine and xylazine was used as much as $0.1 \mathrm{~mL} / 10 \mathrm{~g} \mathrm{BB}$. After the anesthesia stage was reached, with the condition of the animal being sound asleep, the extraction of the tooth began ( $\mathbf{- F i g s .} \mathbf{1}$ and $\mathbf{2}$ ). The incisors and surrounding areas were cleaned with iodine, and then extraction was performed on the left lower incisors using a PT2 (Hu-Friedy) periotome, using special modifications and forceps. Tooth extraction sockets were filled with drug ingredients to be studied ( - Fig. $\mathbf{3}$ ). The extracted mandibular incisors area was then closed using a 5.0 suture monofilament thread. ${ }^{79-11}$

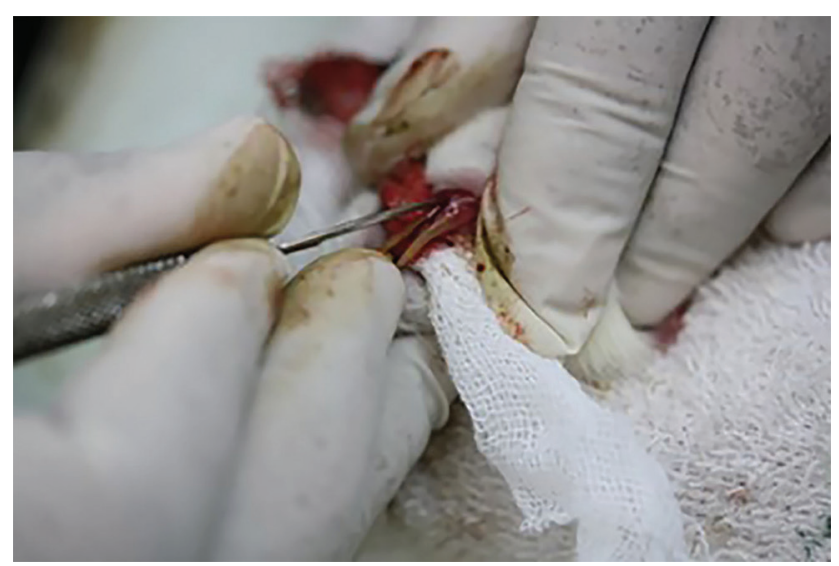

Fig. 1 Wistar rat lower incisor extraction.

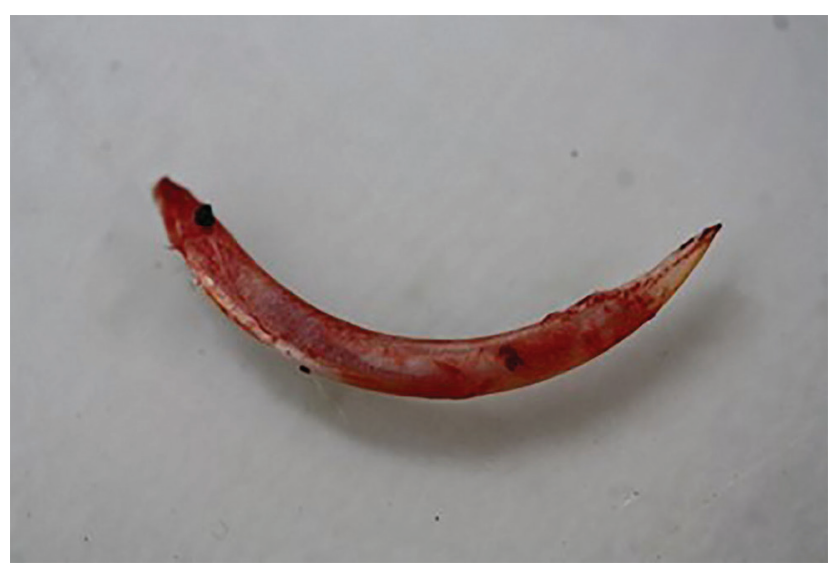

Fig. 2 Wistar rat lower incisor teeth.

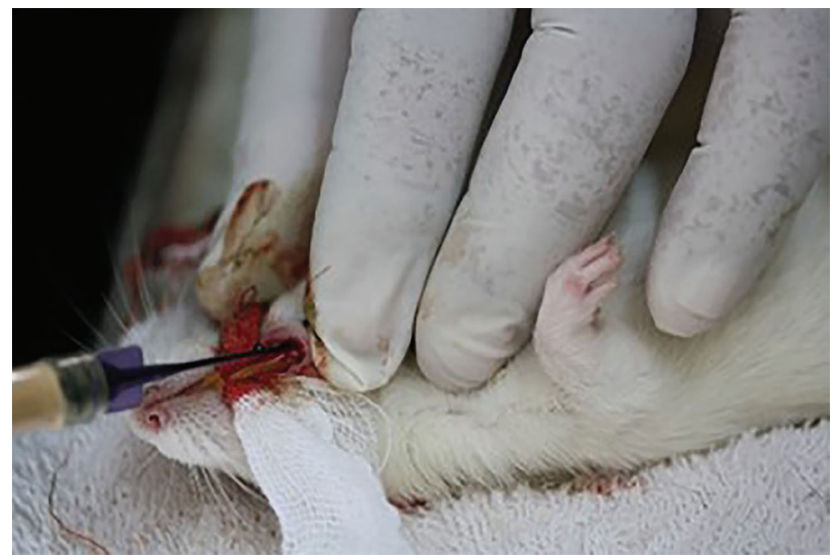

Fig. 3 Application of medicinal ingredients studied in tooth extraction sockets.

\section{Results}

Extraction of mandibular incisors in Wistar rats was performed by carefully refining the lower mandibular, so that the animals did not experience excessive trauma other than that caused by tooth extraction. The process of extraction using special tools was also performed with caution; this was indicated by the incidence of very small tooth roots $(2 \%)$ and the remaining fracture could be removed intact again. The bleeding that occurred (3\%) was stopped by pressing gauze on the wound after extraction and suturing with nylon needle 5.0.

\section{Discussion}

The animal selection process tries to pay attention to replacement, reduction, and refinement. Replacement is the need to use carefully tested experimental animals, both from previous experience and literature. Reduction is the use of animals in research as little as possible, but still getting optimal results. Refinement is humane animal treatment, keeping the animal well, not hurting the animal or minimizing painful treatment to ensure the comfort of the animal until the end of the study.

The use of special tools such as the PT2 (Hu-Friedy) periotome, a modified bein, special pulling pliers are very important for the successful extraction of Wistar rat teeth. Other things that also play an important role in this study include the age of the experimental animals; for example, young adults Wistar rats should be selected, so that tooth extraction is easier. This is because in older animas, cementum root levels are increased, making the extraction of Wistar rat teeth difficult and increasing the potential for fracture. At the time of extraction of the Wistar incisors, the periodontal ligament in the tooth needs to be damaged first by means of a modified bein inserted into the gingiva of the incisors, then after it is felt sufficient, the forceps are used with a semicircular pull. ${ }^{12-14}$ After the tooth extraction is completed, each treatment group is immediately given the material to be researched in each mice group using a blunt-pointed needle. 
Table 1 Incidence of complications during extraction of Wistar rat incisors

\begin{tabular}{|l|l|}
\hline Extraction of incisors & Number of Wistar rats \\
\hline Root tooth fracture & 1 \\
\hline $\begin{array}{l}\text { Death from anesthesia and } \\
\text { infection }\end{array}$ & 0 \\
\hline Hemorrhage & 6 \\
\hline Total & 50 \\
\hline
\end{tabular}

The former extraction area is then closed using a 5.0 monofilament thread, so that the medicinal ingredients to be studied do not flow out of the retractable socket, because Wistar rats are animals that eat through front teeth.

In this study, the level of tooth fracture in extraction was much smaller than the research conducted by Zecchin et al. ${ }^{6}$ No animals died from anesthesia and infection as the extraction was performed on a single root and the experimental animals used were still young, with the alveolar bone more elastic and less cementum (-Table 1). This technique allows researchers to find a drug that can cure tooth extraction wounds faster, as well as study for bone grafts in the alveolar bone.

\section{Conclusion}

The new techniques of extraction can be useful for studying mucosal and alveolar bone healing, specifically finding new types of drugs to accelerate wound healing during alveolar bone post extraction.

\section{Conflict of Interest}

None declared.

\section{Acknowledgments}

The authors are thankful to Faculty of Dentistry, Airlangga University, and Faculty of Veterinary Medicine, Airlangga University, for providing all the type of facilities to conduct this research.

\section{References}

1 Balqis U, Darmawi, Iskandar CD, Salim MN. Angiogenesis activity of. Jatropha curcas. L. latex in cream formulation on wound healing in mice. Vet World 2018;11(7):939-943
2 Yuniarti WM, Lukiswanto BS. Effects of herbal ointment containing the leaf extracts of Madeira vine (Anredera cordifolia (Ten.) Steenis) for burn wound healing process on albino rats. Vet World 2017;10(7):808-813

3 Valizadeh R, Hemmati AS, Houshmand G, Bayat S, Bahadoram M. Wound healing potential of Althaea officinalis flower mucilage in rabbit full thickness wounds. Asian Pac J Trop Biomed 2015;5(11):937-943

4 Bohling MW, Henderson RA. Differences in cutaneous wound healing between dogs and cats. Vet Clin North Am Small Anim Pract 2006;36(4):687-692

5 Graziani F, Laurell L, Tonetti M, Gottlow J, Berglundh T. Periodontal wound healing following GTR therapy of dehiscence-type defects in the monkey: short-, medium- and longterm healing. J Clin Periodontol 2005;32(8):905-914

6 Zecchin KG, Jorge RDS, Jacks Jorge J. A new method for extraction of mandibular first molars in rats. Braz J Oral Sci 2007;6(21):1344-1348

7 Khoswanto C, Soehardjo I. The effect of Binahong Gel (Anredera cordifolia (Ten.) Steenis) in accelerating the escalation expression of HIF- $1 \alpha$ and FGF-2. Journal of International Dental and Medical Research 2018;11(1):303-307

8 Günay A, Arpağ OF, Atilgan S, Yaman F, Atalay Y, Acikan I. Effects of caffeic acid phenethyl ester on palatal mucosal defects and tooth extraction sockets. Drug Des Devel Ther 2014;8:2069-2074

9 Meerlo P, Overkamp GJ, Benning MA, Koolhaas JM, Van den Hoofdakker RH. Long-term changes in open field behaviour following a single social defeat in rats can be reversed by sleep deprivation. Physiol Behav 1996;60(1):115-119

10 Hong YP, Lee HC, Kim HT. Treadmill exercise after social isolation increases the levels of NGF, BDNF, and synapsin I to induce survival of neurons in the hippocampus, and improves depression-like behavior. J Exerc Nutrition Biochem 2015;19(1):11-18

11 Prasanth T, Saraswathi T. Histopathological and radiographic evaluation of rat molar teeth after traumatic injury-a pilot study. J Oral Maxillofac Pathol 2012;16(3):313-317

12 Rahman MNA, Sukmasari S, Doolaanea AA, Qader OAJA. Potential oral wound healing of topical application of dental gel prepared from Baccaurea angulate fruit in diabetic rats. J Pharm Sci Res 2018;10(1):167-174

13 Matsuzawa H, Toriya N, Nakao Y, et al. Cementocyte cell death occurs in rat cellular cementum during orthodontic tooth movement. Angle Orthod 2017;87(3):416-422

14 Ho SP, Yu B, Yun W, Marshall GW, Ryder MI, Marshall SJ. Structure, chemical composition and mechanical properties of human and rat cementum and its interface with root dentin. Acta Biomater 2009;5(2):707-718 